\title{
Appraisal of phytochemical and in vitro biological attributes of an unexplored folklore: Rhus Punjabensis Stewart
}

Saira Tabassum", Madiha Ahmed ${ }^{2}$, Bushra Mirza ${ }^{3}$, Muhammad Naeem¹, Muhammad Zia ${ }^{1 *}$, Zabta Khan Shanwari ${ }^{1}$ and Gul Majid Khan ${ }^{2^{*}}$

\begin{abstract}
Background: The role of plants for discovery of therapeutic potential accentuates the need to know their biological attributes. The present study aims to comprehend the biological attributes of Rhus punjabensis, an unexplored traditional medicinal plant.

Methods: Leaf and stem extracts of $R$. punjabensis prepared in 11 different organic solvents are evaluated for multimode antioxidant potential, total phenolic and flavonoid contents were determined through colorimetric assays, HPLC-DAD analysis was carried out for quantification of various polyphenols in extracts. Brine shrimp lethality, SRB and MTT assays were used to elucidate plant's cytotoxic and antileishmanial potentials. Disc diffusion assay was used to elucidate the protein kinase inhibitory, antibacterial and antifungal spectrum.

Results: Ethanol + ethyl acetate yielded maximum extract recovery from leaf $(6.11 \pm 1.09 \% \mathrm{w} / \mathrm{w})$, total phenolic content $(80.5 \pm 2.18 \mu \mathrm{g} \mathrm{GAE} / \mathrm{mg}$ extract) and reducing power potential (165.4 $\pm 2.29 \mu \mathrm{g} \mathrm{AAE} / \mathrm{mg}$ extract). Maximum flavonoid content $\left(30.50 \pm 1.11 \mu \mathrm{g}\right.$ QE/mg extract) and highest DPPH based free radical scavenging activity $\left({ }^{2} C_{50} 11.4 \pm 2.07\right)$ was exhibited by the methanol + chloroform leaf extract. The methanol extract showed maximum total antioxidant capacity $(74.5 \pm 2.25 \mu \mathrm{g} \mathrm{AAE} / \mathrm{mg} \mathrm{DW})$, protein kinase inhibitory $(12.5 \pm 1.10$ bald phenotype at $100 \mu \mathrm{g} / \mathrm{disc})$ and antifungal (MIC $=25 \mu \mathrm{g} /$ disc against Aspergillus flavus) potential. Reverse phase HPLC-DAD based quantification reveals presence of gallic acid, apigenin, rutin and catechin in various extracts. Brine shrimp lethality assay demonstrated most extracts as highly cytotoxic $\left(\mathrm{LC}_{50}<50 \mathrm{\mu g} / \mathrm{mL}\right)$ whereas chloroform extract of leaf demonstrated maximuminhibition against human leukemia cell line $\left(\mathrm{I}_{50} 7.80 \pm 0.01 \mu \mathrm{g} / \mathrm{mL}\right)$. A significant activity against leishmanial promastigotes was demonstrated by $\mathrm{n}$-hexane leaf extract $\left(\mathrm{IC}_{50}=15.78 \pm 0.15 \mu \mathrm{g} / \mathrm{mL}\right)$. A better antibacterial activity,by the extracts, against Gram positive strains as compared to Gram negative was observed.
\end{abstract}

Conclusions: Results recommend multiple-solvent system as a critical factor to sumptuous the biological prospective of $R$. punjabensis and propose it to be a useful natural hub for the discovery of novel antioxidant, anticancer, antileishmanial and antimicrobial agents.

Keywords: HPLC-DAD, Antioxidant, Brine shrimps cytotoxicity, Anticancer, Antileishmanial

\footnotetext{
* Correspondence: ziachaudhary@gmail.com; m.zia@qau.edu.pk; gmkhan@qau.edu.pk

${ }^{1}$ Department of Biotechnology, Faculty of Biological Sciences, Quaid-i-Azam

University Islamabad, Islamabad 45320, Pakistan

${ }^{2}$ Department of Pharmacy, Faculty of Biological Sciences, Quaid-i-Azam

University Islamabad, Islamabad 45320, Pakistan

Full list of author information is available at the end of the article
}

(c) The Author(s). 2017 Open Access This article is distributed under the terms of the Creative Commons Attribution 4.0 International License (http://creativecommons.org/licenses/by/4.0/), which permits unrestricted use, distribution, and reproduction in any medium, provided you give appropriate credit to the original author(s) and the source, provide a link to the Creative Commons license, and indicate if changes were made. The Creative Commons Public Domain Dedication waiver (http://creativecommons.org/publicdomain/zero/1.0/) applies to the data made available in this article, unless otherwise stated. 


\section{Background}

The exceptionality in structural diversity of Mother Nature has been the most imperative source of novel biomarkers against a number of unremitting and ever more challenging health anomalies since antiquity. As the plant inhabitant secondary metabolites are evolved within living systems, they are often alleged to possess greater drug likeness and biological friendliness. Therefore, there has been a tremendous surge in the phytochemical and biological prospecting of ethnomedicinal herbal remedies nowadays.

The genus Rhus encompassing around 250 species of flowering plants is a well acknowledged ethno-medicinal genus which is extensively used by the local people of Pakistan especially in the Khyber PakhtoonKhwa (KPK) province. It belongs to family Anacardiacaea; comprising of mostly small trees and shrubs, often with a resinous bark and a milky sap, leaves are alternate, simple or compound, flowers are bisexual or unisexual [1]. Sumac is the common name for Rhus, the name is originated from "sumaga" meaning red in Syriac and is recognized to possess both nutritional as well as medicinal importance [2]. Rhus normally grows in non-agricultural regions and is used by indigenous people as food as well as medicinal and other purposes [3]. R. punjabensis Stewart and the allied species of Rhus are widely used in the folk medicine to treat hepatitis and other ailments in the local vicinity of Karak, KPK Pakistan, however scientific literature about this specie is dearth. In traditional system of medicines the Rhus spp. has been used in the treatment of diarrhea, dysentery, ulcer wound healing, leucorrhea, sore of throat, conjunctivitis, ophthalmia, diuresis, animal bites, pain, poison, and liver disease [4]. Bark cocktail is used in treatment of viral eye infections and also applied on forehead as first-aid treatment of epitasis [5]. Powdered fruits are sprinkled on boiled egg and eaten for the treatment of diarrhea [6]. The decoction of fruits is administered orally for the treatment of diarrhea and urinary system disorders as well as liver diseases [4]. Despite of the several claims for other species, scientific data about the biological profile of $R$. punjabensisis still in paucity. To the best of our knowledge this is the first comprehensive report that has unveiled the phytochemical, antioxidant, protein kinase inhibitory, anticancer, antileishmanial and antimicrobial prospective of the subject plant. A range of solvent systems of escalating polarity has been employed to determine the best solvent system for each type of bioactivity. In contrast to the previous studies employing one or two solvent extracts which do not possibly dissolve all phytochemicals, the current study is designed to evaluate the hidden potential of different solvent soluble extracts with reference to the polarity of active compounds present in the herb of $R$. punjabensis.

\section{Methods}

\section{Collection and authentication}

R. punjabensis Stewart was collected in July 2013 from Lakary mountain, Shamshaki, District Karak, Khyber Pakhtunkhwa, Pakistan. The collection site was wild and did not require authorization from any regulatory agency. The plant material was authenticated by Prof. Dr. Mir Ajab Khan, Department of Plant Sciences, Quaid-i-Azam University Islamabad, Pakistan. A voucher specimen HMP 491 was deposited in the Herbarium of Medicinal Plants, Quaid-i-Azam University Islamabad, Pakistan.

\section{Chemicals and reagents}

The study involves use of analytical grade solvents i.e. n-hexane; chloroform; acetone; ethyl acetate; ethanol; methanol and dimethyl sulfoxide (DMSO) purchased from Sigma (Sigma-Aldrich, USA). The reagents include gallic acid; quercetin; 2,2-diphenyl-1-picryl-hydrazyl (DPPH); potassium acetate; aluminum chloride; Folin-Ciocalteu (F-C) reagent; sodium carbonate; ascorbic acid; ammonium molybdate; sodium phosphate; sulfuric acid; ferric cyanide; trichloroacetic acid and potassium ferricyanide procured from Merck (Merck KGaA, Germany), rutin; myricetin; caffiec acid;apigenin;kaempferol; catechin; and caffeic acid were purchased from Sigma (Sigma-Aldrich, Germany). Sabouraud dextrose agar (SDA), nutrient broth and nutrient agar media were purchased from Merck (Merck KGaA, Germany). RPMI-1640, fetal bovine serum (FBS) and medium 199 were purchased from Sigma (Sigma Chemical Co., St. Louis, MO). Equipment included Agilent 1200 series binary gradient HPLC coupled with diode array detector (Agilent Technologies, Germany); $\mathrm{CO}_{2}$ incubator (mco-17AIC,Sanyo-Japan); improved neubauer chamber (Marien, Germany). Reference standards employed in the current study, werepurchased from Sigma-Aldrich USA, include droxithromycin; cefixime; terbinafine; doxorubicin; surfactin; amphotericin-B; 5-Florouracil and vincristine.

\section{Preparation of extracts}

$R$. punjabensis leaves and stem were rinsed with water and dried under shade at room temperature. After comminuting to coarse powder by commercial grinder, $15 \mathrm{~g}$ powder was soaked separately in beakers, each containing $45 \mathrm{~mL}$ of extraction solvents. A variety of solvents were applied ranging from non-polar to highly polar including $n$-hexane (n-hex), chloroform $\left(\mathrm{CHCl}_{3}\right)$, acetone (Acet), ethyl acetate (EtOAc), ethanol (EtOH), methanol $(\mathrm{MeOH})$, ethanol + chloroform $\left(\mathrm{EtOH}+\mathrm{CHCl}_{3} ; \quad 1: 1\right)$, methanol + chloroform $\left(\mathrm{MeOH}+\mathrm{CHCl}_{3} ; 1: 1\right)$, acetone + ethyl acetate (Acet + EtOAc; 1:1), ethanol + ethyl acetate $(\mathrm{EtOH}+\mathrm{EtOAc} ; 1: 1) ;$ and methanol + ethyl acetate $(\mathrm{MeOH}+$ EtOAc; $1: 1)$. After 3 days of soaking, solvent 
was filtered through Whatman no.1 filter paper and the residue was dipped again in respective solvent and filtered again thereafter. The solvents were combined and concentrated under reduced pressure in a rotary evaporator (Buchi, Switzerland) at $45{ }^{\circ} \mathrm{C}$. Percentage yield of extracts was calculated gravimetrically.

\section{Phytochemical screening \\ Determination of total phenolic contents (TPC)}

Total phenolic contents were determined using standard protocol [7]. In brief, stock solutions $(4 \mathrm{mg} / \mathrm{mL})$ of the extracts were prepared in DMSO and $20 \mu \mathrm{L}$ of each was transferred to 96 well plate. Folin-Ciocalteu reagent $(90 \mu \mathrm{L})$ was added to each well and after $5 \min 90 \mu \mathrm{L}$ $\mathrm{Na}_{2} \mathrm{CO}_{3}\left(7.5 \% \mathrm{w} / \mathrm{v}\right.$ in $\left.\mathrm{H}_{2} \mathrm{O}\right)$ was mixed in each well. The reaction mixtures were incubated for $1 \mathrm{~h}$ and absorbance was measured at $630 \mathrm{~nm}$ using microplate reader (Bioteck, USA). Blank (DMSO) and standard (gallic acid in DMSO) were run simultaneously as control. A calibration curve $\left(y=0.0135 x+0.0846, R^{2}=0.986\right)$ was obtained in parallel under the same experimental conditions using gallic acid $(6.25-50 \mu \mathrm{g} / \mathrm{mL})$. The resultant TPC is determined as $\mu \mathrm{g}$ gallic acid equivalent per mg dry weight ( $\mu \mathrm{g} \mathrm{GAE} / \mathrm{mg}$ extract).

\section{Determination of total flavonoid content (TFC)}

Total flavonoid contents were determined according to the method previously described [8]. Briefly 20 $\mu$ Lof sample $(4 \mathrm{mg} / \mathrm{mL}), 10 \mu \mathrm{L}$ of aluminium chloride $\left(10 \% \mathrm{w} / \mathrm{v}\right.$ in $\left.\mathrm{H}_{2} \mathrm{O}\right), 10 \mu \mathrm{L}$ of $1.0 \mathrm{M}$ potassium acetate and $160 \mu$ Lof distilled water were added in 96 well plate which was incubated at room temperature for $30 \mathrm{~min}$. The absorbance of the plate was measured at $415 \mathrm{~nm}$ using microplate reader (Bioteck, USA). The calibration curve $\left(y=0.0269 x+0.00765, \quad R^{2}=0.998\right)$ was drawn by using quercetin as standard at 0 to $40 \mu \mathrm{g} / \mathrm{mL}$ and the flavonoid content were established as $\mu \mathrm{g}$ quercetin equivalent per mg plant extract ( $\mu \mathrm{g}$ $\mathrm{QE} / \mathrm{mg}$ extract).

\section{Quantitative evaluation by HPLC-DAD}

HPLC-DAD analysis of the extracts for polyphenols was carried out following the standard protocol [9]. Each sample was dissolved in methanol at $10 \mathrm{mg} / \mathrm{mL}$ and standards i.e. quercetin, myricetin, catechin, gallic acid, apigenin, kaempferol, caffeic acid, and rutin were prepared as $50 \mu \mathrm{g} / \mathrm{mL}$ in methanol. All the solutions were filtered through $0.2 \mu \mathrm{m}$ sartolon polyamide membrane filter. HPLC system was equipped with C8 analytical column and coupled with diode array DAD detector. For the analysis of poly phenols, the mobile phases were comprised as mobile phase A; acetonitrile-methanolwater-acetic acid $(5: 10: 85: 1)$ and mobile phase $B$; acetonitrile-methanol-acetic acid (40:60:1). The flow rate was maintained at $1 \mathrm{~mL} / \mathrm{min}$. Sample solution $(20 \mu \mathrm{L})$ was injected into the column (Zorbax RX-C8 $4.6 \mathrm{x}$ $250 \mathrm{~mm}, 5 \mu \mathrm{m}$ ) followed by a column reconditioning for 10 min before next analysis. The gradient volume of $\mathrm{B}$ was $0-50 \%$ in $0-20 \mathrm{~min}, 50-100 \%$ in $20-25 \mathrm{~min}$ and then $100 \%$ from 25 to $30 \mathrm{~min}$. The absorption of samples was recorded at $257 \mathrm{~nm}$ (rutin and gallic acid), $279 \mathrm{~nm}$ (catechin), $325 \mathrm{~nm}$ (caffeic acid) and $368 \mathrm{~nm}$ (myricetin, querecetin, kaempferol and Apeginin).

\section{Biological evaluation}

\section{Determination of total antioxidant capacity (TAC)}

Phosphomolybdenum based colorimetric assay was employed to determine total antioxidant capacity and is expressed as $\mu \mathrm{g}$ equivalent to ascorbic acid per mg plant dry weight ( $\mu \mathrm{g} \mathrm{AAE} / \mathrm{mg}$ extract) [7] with slight modification. An aliquot of $0.1 \mathrm{~mL}$ of each extract $(4 \mathrm{mg} / \mathrm{mL}$ in DMSO) was mixed with $0.9 \mathrm{~mL}$ of reagent $(0.6 \mathrm{M}$ sulphuric acid, $28 \mathrm{mM}$ sodium phosphate and $4 \mathrm{mM}$ ammonium molybdate solution in $\mathrm{H}_{2} \mathrm{O}$ ). Blank contained $0.9 \mathrm{~mL}$ of reagent solution and $0.1 \mathrm{~mL}$ of DMSO without extract; while $4 \mathrm{mg} / \mathrm{mL}$ ascorbic acid served as positive control. All tubes were kept in water bath for $90 \mathrm{~min}$ at $95{ }^{\circ} \mathrm{C}$ and then cooled to room temperature. A volume of $200 \mu \mathrm{L}$ was transferred to 96 well plate and the absorbance was measured at $630 \mathrm{~nm}$ using microplate reader (Biotech USA, microplate reader Elx 800). A calibration curve $\left(y=0.0211 x+0.0920, R^{2}=0.9911\right)$ of ascorbic acid was prepared at final concentrations of $100,50,25,12.5,6.25,3.12 \mu \mathrm{g} / \mathrm{mL}$.

\section{Reducing power assay}

Standard potassium ferricyanide colorimetric assay was performed to estimate the reducing power potential of extracts [9]. An aliquot of $200 \mu \mathrm{L}$ of extracts $(4 \mathrm{mg} / \mathrm{mL}$ DMSO) was mixed with $400 \mu \mathrm{L}$ of phosphate buffer $(0.2 \mathrm{~mol} / \mathrm{L}, \mathrm{pH} 6.6)$ and potassium ferricyanide $(1 \% \mathrm{w} / \mathrm{v}$ in $\mathrm{H}_{2} \mathrm{O}$ ). The mixture was incubated for $20 \mathrm{~min}$ at $50{ }^{\circ} \mathrm{C}$ followed by addition of $400 \mu \mathrm{L}$ of trichloroacetic acid $\left(10 \% \mathrm{w} / \mathrm{v}\right.$ in $\left.\mathrm{H}_{2} \mathrm{O}\right)$ and centrifuged at $3000 \mathrm{rpm}$ at room temperature for $10 \mathrm{~min}$. The upper layer of solution $(500 \mu \mathrm{L})$ was mixed with distilled water $(500 \mu \mathrm{L})$ and $100 \mu \mathrm{L}$ of $\mathrm{FeCl}_{3}\left(0.1 \% \mathrm{w} / \mathrm{v}\right.$ in $\left.\mathrm{H}_{2} \mathrm{O}\right)$. From this mixture, $200 \mu \mathrm{L}$ was transferred to 96 well plate and absorbance of the reaction mixture was measured at $630 \mathrm{~nm}$. Blank was prepared by adding $200 \mu \mathrm{L}$ DMSO to the aforesaid reaction mixture instead of extract. A calibration curve $\left(y=0.037 x+0.7482, R^{2}=\right.$ 0.9961) of ascorbic acid was obtained at final concentrations of $100,50,25,12.5,6.25,3.12 \mu \mathrm{g} / \mathrm{mL}$ and the resultant reducing power of each sample is expressed as $\mu \mathrm{g} \mathrm{AAE} / \mathrm{mg}$ extract. 


\section{DPPH free radical scavenging assay}

The DPPH free radical scavenging activity of extracts was evaluated by monitoring their capability to quench the stable 2, 2-diphenyl-1-picrylhydrazyl (DPPH) free radical $[7,10,11]$. Briefly, $20 \mu \mathrm{L}$ of four different dilutions of each sample with final concentrations of 200 , 66.66, 22.22 and $7.41 \mu \mathrm{g} / \mathrm{mL}$, were mixed with $180 \mu \mathrm{L}$ of DPPH solution $(9.2 \mathrm{mg} / 100 \mathrm{~mL}$ in methanol). After incubating the plate for $30 \mathrm{~min}$ at $37^{\circ} \mathrm{C}$, absorbance was recorded at $515 \mathrm{~nm}$. Percent free radical scavenging activity (\%FRSA) was calculated by using the formula:

$$
\% \text { FRSA }=\left(1-\mathrm{Ab}_{\mathrm{s}} / \mathrm{Ab}_{\mathrm{c}}\right) \times 100
$$

Where $A b_{s}$ is the absorbance of test sample, whereas $A b_{c}$ is the absorbance of negative control containing the DMSO instead of sample. Ascorbic acid was used as positive control. Afterwards $\mathrm{IC}_{50}$ of samples with significant radical scavenging efficiency $(>50 \%)$ was also calculated.

\section{Brine shrimp lethality assay}

Lethality test was performed in a 96 well plate using brine shrimp (Artemiasalina) larvae as previously described (Bibi et al., 2011) with slight modification. $A$. salina eggs (Ocean star, USA) were incubated for 24$48 \mathrm{~h}$ under light at $30-32{ }^{\circ} \mathrm{C}$ in simulated sea water ( $38 \mathrm{~g} / \mathrm{L}$ supplemented with $6 \mathrm{mg} / \mathrm{L}$ dried yeast) in a specially designed two-compartment plastic tray. Ten mature phototropic nauplii were harvested with the help of Pasteur pipette and transferred to each well of plate. Corresponding volume of each extract containing $\leq 1 \%$ DMSO in sea water at final concentrations of 200, 100, 50 and $25 \mu \mathrm{g} / \mathrm{mL}$ was transferred to the wells containing sea water and shrimp larvae. The final volume in each well was kept $300 \mu \mathrm{L}$. Positive and negative control wells included serial concentrations of doxorubicin and 1\% DMSO, respectively. After $24 \mathrm{~h}$ incubation, live shrimps were counted and percentage of deaths was determined. Median lethal concentration $\left(\mathrm{LC}_{50}\right)$ was calculated using table curve 2D v5.01 software.

\section{Protein kinase inhibition assay}

The assay was accomplished by Streptomyces $85 \mathrm{E}$ strain according to previously documented procedure [12] with slight modification. Streptomyces was refreshed in sterile trypton soy broth (Merck, Germany) for $48 \mathrm{~h}$ and the revived culture was inoculated on petri plates containing ISP4 mineral medium. Each test sample $(5 \mu \mathrm{L}$ of $20 \mathrm{mg}$ / $\mathrm{mL}$ as $100 \mu \mathrm{g} / \mathrm{disc}$ ) was impregnated on $6 \mathrm{~mm}$ Whatman filter paper sterile disc and placed on seeded plates. The plates were incubated at $28{ }^{\circ} \mathrm{C}$ for $72 \mathrm{~h}$ to allow the development of hyphae. The bald zone of hyphae formation inhibition was measured with the help of vernier calliper. Extracts producing an inhibition zone $\geq 10 \mathrm{~mm}$ in diameter were screened to determine minimum inhibitory concentrations (MICs) at lower concentrations ranging from 50 to $3.12 \mu \mathrm{g} /$ disc. Surfactin $(5 \mu \mathrm{L}$ of $4 \mathrm{mg} / \mathrm{mL}$ in DMSO) and DMSO impregnated discs served as positive and negative controls, respectively.

\section{Cytotoxicity against THP-1 leukemia cell line}

The in vitro cytotoxicity evaluation of extracts against humanleukemia (THP-1) cell line (ATCC \# TIB-202) was performed using standard protocol [13] with slight modifications. Briefly, leukemia cells were grown in growth medium [RPMI-1640 buffered with $2.2 \mathrm{~g} / \mathrm{LNaHCO}_{3}$ and supplemented with $10 \% \mathrm{v} / \mathrm{v}$ heat inactivated fetal bovine serum (HIFBS); $\mathrm{pH}$ 7.4] in a humidified carbon dioxide incubator $\left(37{ }^{\circ} \mathrm{C}, 5 \% \mathrm{CO}_{2}\right)$. An aliquot of $190 \mu \mathrm{L}$ of THP-1 cells (seeding density of $1 \times 10^{4}$ cells per $\mathrm{mL}$ ) was transferred to each well of 96 well plate having $10 \mu \mathrm{L}$ of sample containing 1\% DMSO in PBS corresponding to final concentration of $20 \mu \mathrm{g} / \mathrm{mL}$. The culture was incubated at $37^{\circ} \mathrm{C}$ for $72 \mathrm{~h}$ in humidified $\mathrm{CO}_{2}$ (5\%) incubator. Serial concentrations of fluorouracil and vincristine were employed as positive controls whereas $1 \%$ DMSO in PBS served as negative control. Afterwards, $20 \mu \mathrm{L}$ of pre-filter sterilized MTT solution $(4 \mathrm{mg} / \mathrm{mL}$ in distilled $\mathrm{H} 2 \mathrm{O})$ was added and plates were again incubated at $37{ }^{\circ} \mathrm{C}$ for $4 \mathrm{~h}$ in humidified $\mathrm{CO}_{2}$ (5\%) incubator. After incubation $170 \mu \mathrm{L}$ supernatant was removed carefully by using micropipette without disturbing colored formazan sediments. To dissolve the formazan sediments $100 \mu \mathrm{L}$ of DMSO was added in each well, the plate was kept aside for one $\mathrm{h}$ to ensure full dissolution and the absorbance was measured at $540 \mathrm{~nm}$ using microplate reader. Samples showing more than $50 \%$ cell mortality at $20 \mu \mathrm{g} / \mathrm{mL}$ were further analyzed at lower concentrations i.e. $10,5,2.5$ and $1.25 \mu \mathrm{g} / \mathrm{mL}$. $\mathrm{LC}_{50}$ was calculated using table curve 2D v5.01 software.

\section{Antibacterial activity Disc diffusion method}

Susceptibility of extracts against bacterial species was tested according to formerly described procedure [14]. Two Gram positive (Micrococcus luteus ATCC \# 10240 and Staphylococcus aureus ATCC \# 6538) and three Gram negative strains (Bordetella bronchiseptica ATCC \# 4617, Salmonella typhimurium ATCC \# 14028 and Enterobacter aerogenes ATCC \# 13048) were tested. The strains were cultured in nutrient broth media and incubated for $24 \mathrm{~h}$ at $37^{\circ} \mathrm{C}$. Sterilized deionized water was used to adjust the turbidity to $10^{4} \mathrm{CFU} / \mathrm{mL}$ by comparing with McFarland $0.5 \mathrm{BaSO}_{4}$ turbidity standards. The refreshed inoculum $(100 \mu \mathrm{L})$ was then swabbed onto Petri plates containing $20 \mathrm{~mL}$ nutrient agar. Test samples $(5 \mu \mathrm{L}$ of $20 \mathrm{mg} / \mathrm{mL}$ DMSO; $100 \mu \mathrm{g} /$ disc) were infused on sterile filter paper discs $(6 \mathrm{~mm})$ and placed on seeded nutrient agar plate. Roxithromycin and Cefixime- 
USP at a concentration of $20 \mu \mathrm{g} /$ disc and DMSO impregnated discs were included as positive and negative controls, respectively. After $24 \mathrm{~h}$ incubation, clear zones of growth inhibition were measured.

\section{Broth micro-dilution method}

The samples having $\geq 10 \mathrm{~mm}$ zone of inhibition (ZOI) were tested at lower concentrations using standard three-fold micro broth dilution method [15]. Test $50 \mu \mathrm{L}$ of each bacterial suspension in suitable growth medium was added to the wells of a sterile 96-well microtitre plate already containing plant extract was serially diluted with nutrient broth to obtain a concentration ranging from $100 \mu \mathrm{g} / \mathrm{mL}$ to $1.11 \mu \mathrm{g} / \mathrm{mL}$. The final volume in each well was $100 \mu \mathrm{L}$. Control wells were prepared with culture medium bacterial suspension only. The contents of each well were mixed on a microplate shaker (Hamburg, Germany) at $900 \mathrm{rpm}$ for $1 \mathrm{~min}$ prior to incubation for $24 \mathrm{~h}$. The plates were incubated for $24 \mathrm{~h}$ in dark at $37{ }^{\circ} \mathrm{C}$. After incubation the plates were analyzed visually to determine the growth of bacteria in the respective well. The minimum concentration of sample showing no growth was taken as MIC (minimum inhibitory concentration).

\section{Antifungal activity}

Antifungal activity of extracts was evaluated following previously described standard protocol [14]. The fungal strains (Aspergillus fumigates FCBP \# 66, Fusarium solani FCBP \# 0291, Mucor specie FCBP \# 0300, Aspergillus flavus FCBP \# 0064 and Aspergillus niger FCBP \# 0198; purchased from fungal culture bank of Pakistan) were cultured on SDA. Prior to the sensitivity determination, the spores were harvested in $0.02 \%$ Tween 20 solution and turbidity was adjusted according to McFarland 0.5 turbidity standard. The $100 \mu \mathrm{L}$ of respective harvested spores was swabbed on plates containing $25 \mathrm{~mL}$ sterilized SDA. Filter paper discs loaded with $5 \mu \mathrm{L}$ of test sample ( $20 \mathrm{mg} / \mathrm{mL}$ DMSO; $100 \mu \mathrm{g} /$ disc) as well as standard antifungal terbinafine $(50 \mu \mathrm{g} / \mathrm{disc})$ and DMSO were placed on seeded SDA plates. The plates were incubated at $28{ }^{\circ} \mathrm{C}$ for $24-48 \mathrm{~h}$. Thereafter, clear zones of inhibition around discs were measured using vernier caliper.

\section{Antileishmanial activity}

The in vitro antileishmanial evaluation of test extracts was carried out by employing MTT colorimetric assay [16]. A 6-7 days incubated culture of Leishmania tropica kwh 23 promastigotes was used. Concisely, parasites were grown in Medium 199 supplemented with $10 \%$ foetal bovine serum (FBS), $100 \mu \mathrm{g} / \mathrm{mL}$ streptomycin sulphate and $100 \mathrm{IU} / \mathrm{mL}$ penicillin $\mathrm{G}$ at $24{ }^{\circ} \mathrm{C}$. An aliquot of $180 \mu \mathrm{L}$ of promastigote culture at a pre-adjusted seeding density of $1 \times 10^{6}$ promastigotes $/ \mathrm{mL}$ was transferred to each well of 96 well plate having $20 \mu \mathrm{L}$ of test samples (containing $\leq 1 \%$ DMSO in PBS). Amphotericin B $(0.33-0.004 \mu \mathrm{g} / \mathrm{mL})$ and $1 \%$ DMSO in PBS instead of test sample were employed as positive and negative controls, respectively. The culture plate was incubated at $24{ }^{\circ} \mathrm{C}$ for $72 \mathrm{~h}$ after that $20 \mu \mathrm{L}$ of pre-filter sterilized MTT solution $\left(4 \mathrm{mg} / \mathrm{mL}\right.$ in distilled $\left.\mathrm{H}_{2} \mathrm{O}\right)$ was added and plates were again incubated at $24{ }^{\circ} \mathrm{C}$ for $4 \mathrm{~h}$. After incubation supernatant was removed carefully without disturbing colored formazan sediments. To dissolve the formazan sediments $100 \mu \mathrm{L}$ of DMSO was added in each well, the plate was kept aside for $1 \mathrm{~h}$ to ensure full dissolution and the absorbance was measured at $540 \mathrm{~nm}$ using microplate reader. Samples showing more than $50 \%$ cell mortality at $100 \mu \mathrm{g} / \mathrm{mL}$ were further analyzed at lower concentrations i.e. 33.3, 11.1, 3.7 and $1.23 \mu \mathrm{g} /$ mL.LC 50 was calculated by using table curve $2 \mathrm{D}$ v5.01 software.

\section{Statistical analysis}

All the experiments were carried out in triplicate. The data were presented as mean \pm standard deviation (SD). SPSS Ver. 21 software was used for Post Hoc Multiple Comparison test in One Way ANOVA and $\mathrm{IC}_{50}$ was determined by using table curve software 2D Ver. 4.

\section{Results and discussion}

R. punjabensis stewart leaves and stem extracts were prepared in varied polarities solvents and maximum extract yield was obtained by $\mathrm{EtOH}+\mathrm{EtOAc}(6.11 \%)$ and $\mathrm{CHCl}_{3}$ (5.49\%) from leaf and stem parts, respectively (Table 1). n-Hex extract exhibited the minimum yield ( 1.25 and $0.56 \%$ from leaf and stem parts, respectively). The difference in extraction yield from different plant parts in similar solvents depicts organ specific accumulation of secondary metabolites in $R$. punjabensis stewart. The extraction is also based on solubility of chemical constituents on polarity basis, it essential to study about the relationship between the extraction methodapplied and their physiochemical properties to substances to be extracted (Medziga et al., 2010).

Isolation of natural compounds, in particular, plantderived antioxidants has gained interest of scientists to treat diseases by reducing oxidative stress [17]. The Highest TPC $(80.5 \pm 2.18 \mu \mathrm{g}$ GAE/mg extract $)$ was quantified in $\mathrm{MeOH}+\mathrm{CHCl}_{3}$ extract of leaves, followed by the $\mathrm{EtOH}+\operatorname{EtOAc}(75.5 \pm 1.75 \mu \mathrm{g} \quad \mathrm{GAE} / \mathrm{mg}$ extract $)$ (Fig. 1). In case of stem, significant quantity was noticed in $\mathrm{MeOH}$ extract $(51.1 \pm 1.14 \mu \mathrm{g}$ GAE$/ \mathrm{mg}$ extract $)$ followed by $\mathrm{MeOH}+\mathrm{CHCl}_{3}(45.4 \pm 1.11 \mu \mathrm{g} \mathrm{GAE} / \mathrm{mg}$ extract) (Fig. 2). The phenolic contents in leaf were found higher in moderately polar solvents. This is in agreement with previous studies, where polar solvent are reported 
Table 1 Percent extract recoveries of leaf and stem of $R$. punjabensis using different solvents

\begin{tabular}{lll}
\hline Samples & \multicolumn{2}{l}{ \%Extract Recovery } \\
\cline { 2 - 3 } & Leaf & Stem \\
\hline n-hex & $1.25 \pm 0.82$ & $0.56 \pm 0.02$ \\
$\mathrm{CHCl} 3$ & $2.44 \pm 0.15^{*}$ & $5.49 \pm 0.22^{* * *}$ \\
Acet & $4.69 \pm 1.04$ & $2.00 \pm 0.43$ \\
Acet + EtOAc & $5.83 \pm 1.21^{* * *}$ & $2.05 \pm 0.08^{*}$ \\
EtOAc & $3.71 \pm 0.09$ & $2.08 \pm 0.87$ \\
EtOH & $3.89 \pm 1.08$ & $2.25 \pm 0.07$ \\
$\mathrm{MeOH}$ & $4.90 \pm 1.03^{* *}$ & $3.34 \pm 0.23^{* *}$ \\
$\mathrm{MeOH}+\mathrm{CHCl3}$ & $5.29 \pm 1.54^{* * *}$ & $2.44 \pm 0.04$ \\
$\mathrm{EtOH}+\mathrm{CHCl3}$ & $3.53 \pm 1.21$ & $2.07 \pm 0.14^{*}$ \\
$\mathrm{EtOH}+\mathrm{EtOAc}$ & $6.11 \pm 1.09^{* * *}$ & $2.48 \pm 0.07$ \\
$\mathrm{MeOH}+\mathrm{EtOAc}$ & $5.20 \pm 1.23$ & $2.83 \pm 0.98^{*}$ \\
\hline Values (man
\end{tabular}

Values (mean \pm SD) are average of three samples of each plant part, analyzed individually in triplicate $(n=1 \times 3 \times 3)$. Data is presented as highly significant***, slightly significant**, significant* at $p<0.05 . n$-hexane: $n$-hex, chloroform: $\mathrm{CHCl}_{3}$, acetone: Acet, ethyl acetate: EtOAc, ethanol: $\mathrm{EtOH}$, methanol: $\mathrm{MeOH}$, ethanol + chloroform: $\mathrm{EtOH}+\mathrm{CHCl}_{3}$, methanol + chloroform: $\mathrm{MeOH}+\mathrm{CHCl}_{3}$ acetone + ethyl acetate: Acet + EtOAc, ethanol + ethyl acetate: $\mathrm{EtOH}+\mathrm{EtOAc}$, methanol + ethyl acetate: $\mathrm{MeOH}+\mathrm{EtOAc}$ efficient for the extraction of phenolics in other Rhus species $[18,19]$. Significant TFC $(30.50 \pm 1.11 \mu \mathrm{g}$ QE/mg extract) was found in $\mathrm{MeOH}+\mathrm{CHCl}_{3}$ leaf extract, followed by $\mathrm{EtOH}+\mathrm{EtOAc}$ extract $(20.1 \pm 0.75 \mu \mathrm{g} \mathrm{QE} /$ mg extracts); while in case of stem highest TFC was found in $\mathrm{MeOH}(19.5 \pm 0.75 \mu \mathrm{g} \mathrm{QE} / \mathrm{mg}$ extract). Antioxidant capability of phenols attribute to the presence of methoxy, hydroxyl, double bond conjugation or ketonic group in a phenolic molecule [4]. In a previous study, flavonols likequercetin, myricetin, and kaempferol have been identified in EtOAc and $\mathrm{MeOH}$ extracts of Rhus coriaria $L$ leaves along with gallic acid, methyl gallate, $m$-digallic acid, and ellagic acid as a part of tannins [20]. Flavonoids produce antioxidative effects and also are potent neuro protective and anti-inflammatory effects as depicted by $R$. verniciflua $L$ bark extract [21]. It can be depicted that as $R$. punjabensis has significantly high amount of flavonoids in its extracts, it may have the above mentioned flavonoids in it For the purpose, quantification of some flavonoids and phenols in extract was carried out by reverse phase HPLC. Significant amount of flavonoid glycosides, flavone aglycones and gallic acid were quantified in some extracts. Among the leaf extracts, substantial amount of rutin was detected in the $\mathrm{EtOH}$ extract $(0.01 \mu \mathrm{g} / \mathrm{mg}$ extract $)$ and $\mathrm{MeOH}$ extract

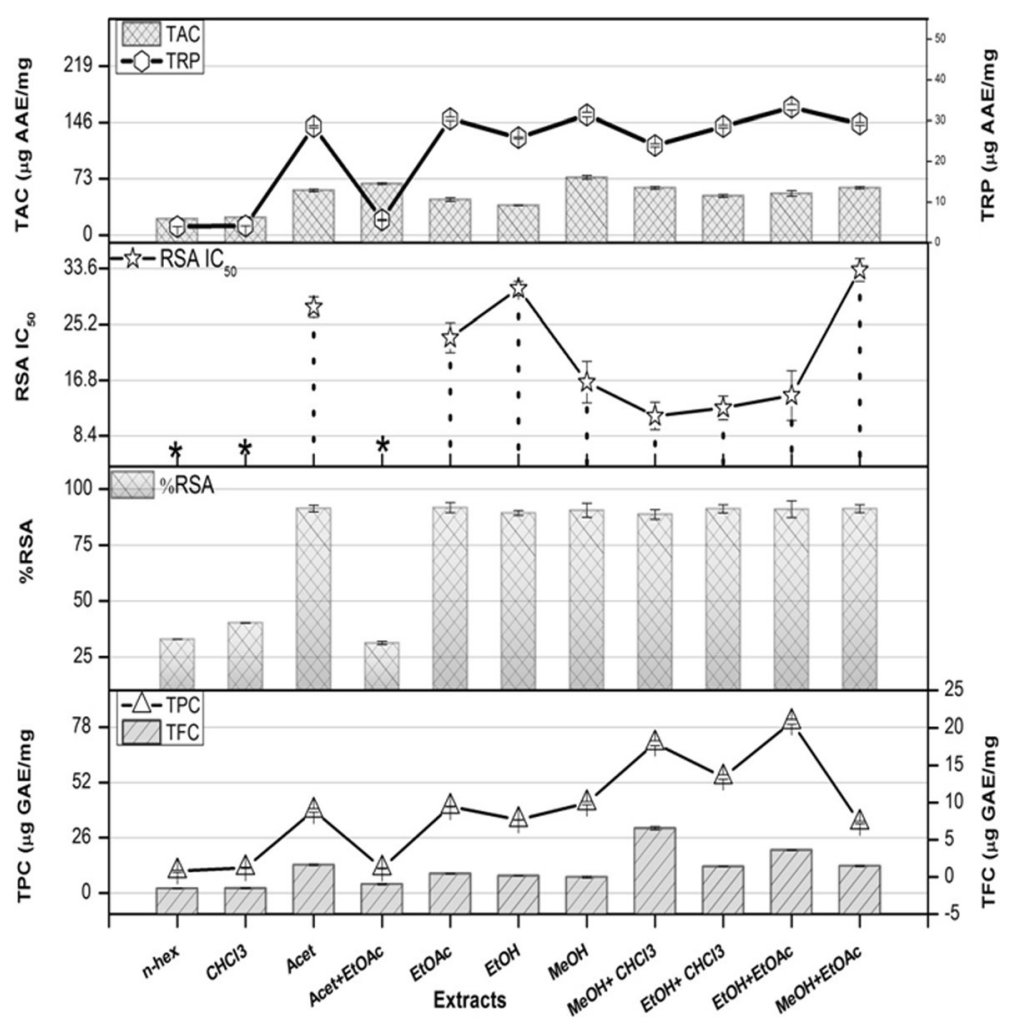

Fig. 1 TPC (Total phenolic content $\mu \mathrm{g}$ GAE/mg extract), TFC (Total flavonoid content $\mu \mathrm{g}$ QE/mg extract), \%RSA (radical scavenging activity), TAC (Total antioxidant capacity $\mu \mathrm{g}$ AAE/mg extract) and TRP (Total reducing power $\mu \mathrm{g}$ AAE/mg extract) potential of $R$. punjabensis Leaf. ${ }^{*} \mathrm{C} 50>200 \mu \mathrm{g} / \mathrm{ml}$ Values are presented as mean \pm Standard error from triplicate investigation 


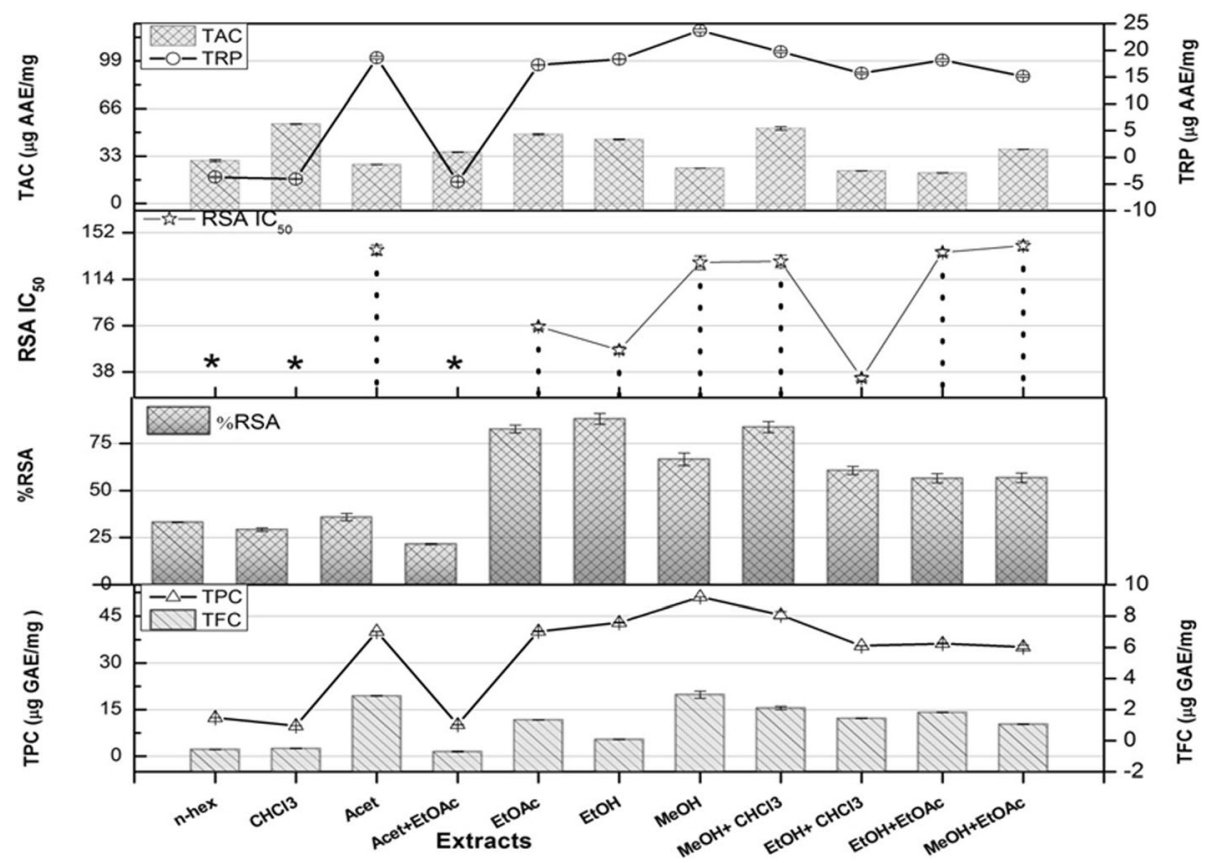

Fig. 2 TPC (Total phenolic content $\mu \mathrm{g}$ GAE/mg extract), TFC (Total flavonoid content $\mu \mathrm{g}$ QE/mg extract), \%RSA (radical scavenging activity), TAC (Total antioxidant capacity $\mu \mathrm{g}$ AAE/mg extract) and TRP (Total reducing power $\mu \mathrm{g}$ AAE/mg extract) potential of R. punjabensis Stem. ${ }^{*}$ IC50> 200 $\mu \mathrm{g} / \mathrm{ml}$ Values are presented as mean \pm Standard error from triplicate investigation

(0.3 $\mathrm{\mu g} / \mathrm{mg}$ extract). Maximum content of gallic acid (0.6 $\mathrm{\mu g} / \mathrm{mg}$ extract) and catechin $(0.8 \mu \mathrm{g} / \mathrm{mg}$ extract $)$ were quantified in $\mathrm{EtOH}+\mathrm{CHCl}_{3}$ leaf extract. Rutin $(0.4 \mu \mathrm{g} / \mathrm{mg}$ extract $)$ and apigenin $(0.6 \mu \mathrm{g} / \mathrm{mg}$ extract $)$ were also significantly present in $\mathrm{MeOH}+\mathrm{CHCl}_{3}$ stem extract (Table 2). Chromatographic fingerprinting by HPLC is considered a simple, reproducible, sensitive and reliable method for chemical profiling of analytes [9]. The flavonoids under investigation possess significant biological activities. For example rutin contributes to antibacterial and antioxidant properties, while gallic acid and apigenin induce autophagy in leukemia cells, which proves their chemo preventive and anticancer role [22]. Previously existence of rutin and other flavonoids establish significant correlation with momentous antioxidant and antibacterial potential of $R$. verniciflualaquer. Flavonoids such as myricetin, quercetin, kaempferoletc has been reported in $R$. coriaria. $L$ [23]. and bear significant antioxidant and cytotoxic activities [24, 25]. The previous reports on other Rhus spp. are in accordance with the current investigation.

Significant antioxidant capacity $(74.5 \pm 2.25 \mu \mathrm{g}$ AAE/mg extract) was observed in $\mathrm{MeOH}$ extract of leaf followed by the Acet + EtOAc extract $(66.9 \pm 1.11 \mu \mathrm{g} \mathrm{AAE} / \mathrm{mg}$ extracts) (Fig. 1). Among stem extracts (Fig. 2), the highest $\mathrm{TAC}(54.4 \pm 1.12 \mu \mathrm{g}$ AAE$/ \mathrm{mg}$ extract $)$ was found in $\mathrm{CHCl}_{3}$ extract followed by $\mathrm{MeOH}+\mathrm{CHCl}_{3}$ extract (52.3 \pm $1.16 \mu \mathrm{g} \mathrm{AAE} / \mathrm{mg}$ extract). The plants have the major potential for the natural antioxidants, phytochemicals and secondary metabolites [26]. Maximum activities shown by $\mathrm{EtOH}$ and $\mathrm{EtOH}+\mathrm{CHCl}_{3}$ can be accredited to the presence of gallic acid, rutin and catechin as indicated by HPLC in this report. Phenolic compounds disrupt chain oxidation reactions by donation of a hydrogen atom or chelating metals. The high amounts of phenolic compounds indicate high antioxidant and reducing power activities [27]. Positive correlation has been found among reducing power, antioxidant, total phenolic, and total flavonoids contents specifically in moderately polar solvents, that is in good agreement with previously documented reports [28].

In TRP assay, yellow color of test solution changes to green or blue depending on the reducing power of samples. The Highest reducing power potential (165.4 \pm $2.29 \mu \mathrm{g}$ AAE/mg extract) was observed by EtOH + EtOAc leaf extract followed by $\mathrm{MeOH}$ extract $(68.94 \pm 3.76 \mu \mathrm{g}$ $\mathrm{AAE} / \mathrm{mg}$ extract) (Fig. 1). In case of stem, the highest TRP was quantified in $\mathrm{MeOH}$ extract $(120.2 \pm 1.12 \mu \mathrm{g}$ AAE/mg extracts) followed by $\mathrm{MeOH}+\mathrm{CHCl}_{3}$ extract (Fig. 2). Previous studies depict that comparatively polar extracts show high reducing power [29]. The presence of rutin in $\mathrm{MeOH}+\mathrm{CHCl}_{3}$ stem extract can be the possible cause of its maximum reducing power as interaction of rutin with superoxide ion and ferrous ions can cause effective inhibition of iron iondependent lipid peroxidation systems [30]. However, 
Table 2 Chemical profiling of stem and leaf extracts of $R$. punjabensis using HPLC-DAD

\begin{tabular}{|c|c|c|c|c|c|}
\hline \multirow[t]{2}{*}{ Samples } & \multicolumn{5}{|c|}{ Polyphenols ( $\mu \mathrm{g} / \mathrm{mg} \mathrm{DW})$} \\
\hline & Gallic acid & Rutin & Caffeic acid & Catechin & Apigenin \\
\hline \multicolumn{6}{|l|}{ Leaf } \\
\hline n-hex & - & - & - & - & - \\
\hline $\mathrm{CHCl} 3$ & - & - & - & - & - \\
\hline Acet & - & - & - & - & - \\
\hline Acet + EtOAc & - & - & - & - & - \\
\hline EtOAc & - & - & - & - & - \\
\hline $\mathrm{EtOH}$ & - & $0.1^{d}$ & - & - & - \\
\hline $\mathrm{MeOH}$ & $0.5^{c}$ & $0.3^{\mathrm{ab}}$ & - & - & - \\
\hline $\mathrm{MeOH}+\mathrm{CHCl} 3$ & $0.6^{\mathrm{b}}$ & - & - & $0.3^{\mathrm{ab}}$ & - \\
\hline $\mathrm{EtOH}+\mathrm{CHCl} 3$ & - & - & - & - & - \\
\hline $\mathrm{EtOH}+\mathrm{EtOAC}$ & - & - & - & - & - \\
\hline $\mathrm{MeOH}+\mathrm{EtOAC}$ & - & - & - & - & - \\
\hline \multicolumn{6}{|l|}{ Stem } \\
\hline n-hex & - & - & - & - & - \\
\hline $\mathrm{CHCl3}$ & - & - & - & - & - \\
\hline Acet & - & - & - & - & - \\
\hline Acet + EtOAc & - & - & - & - & - \\
\hline EtOAc & 0.1 & - & - & - & - \\
\hline $\mathrm{EtOH}$ & - & - & - & - & - \\
\hline $\mathrm{MeOH}$ & $0.8^{\mathrm{a}}$ & - & - & - & - \\
\hline $\mathrm{MeOH}+\mathrm{CHCl} 3$ & $0.4^{c}$ & $0.4^{c}$ & - & - & $0.6^{\mathrm{b}}$ \\
\hline $\mathrm{EtOH}+\mathrm{CHCl} 3$ & $0.2^{\mathrm{e}}$ & - & - & - & $0.3^{\mathrm{ab}}$ \\
\hline $\mathrm{EtOH}+\mathrm{EtOAC}$ & - & - & - & - & - \\
\hline $\mathrm{MeOH}+\mathrm{EtOAc}$ & - & - & - & - & - \\
\hline
\end{tabular}

$=$ not detected. Myricetin, Kaempferol,Quecetin were not detected in all extracts. LSD and HSD applied all the data. The small alphabates marked on values show significantly difference within mean values within cloumn using LSD test at $p<0.05$

absence of quantified flavonoids in $\mathrm{MeOH}+\mathrm{CHCl}_{3}$ leaf extract by HPLC-DAD analysis suggests the probable role of additional flavonoids; require further exploration.

DPPH free radical scavenging potential is based on the ability of antioxidants to decolorize 2, 2-diphenyl-2picryl-hydrazyl. Among all the extracts analyzed, the $\mathrm{IC}_{50}$ ranged from 11.4 to $33.4 \mu \mathrm{g} / \mathrm{mL}$ (Fig. 1). $\mathrm{MeOH}+$ EtoAc leaf extract showed highest DPPH scavenging activity $\left(\mathrm{IC}_{50}\right)$ inhibitory concentration $\left(\mathrm{IC}_{50} 11.4 \mu \mathrm{g} / \mathrm{mL}\right)$. In case of stem extract, considerable DPPH scavenging activity was observed by $\mathrm{EtOH}+\mathrm{CHCl}_{3}$ extract $\left(\mathrm{IC}_{50}\right.$ $33.8 \mu \mathrm{g} / \mathrm{mL}$ ). Studies have demonstrated that free radical scavenging activities might be attributed to the presence of phenolics as a good correlation has been found between the total phenolic content and free radical scavenging activity $\left(R^{2}=0.878\right) . R$. vericiflua stroke has been reported that exhibit marked antioxidant and antitumor properties, and also antioxidant activity on the $\mathrm{Fe}^{+2}$ induced linoleic acid peroxidation [24]. In traditionally the Most of the research performed on Rhus extracts has examined antioxidant activity. The work to date has been focused on various number of species ( $R$. verniciflua and $R$. succedanea in Asia, $R$. hirta in northeastern North America) and $R$. coriaria in the Mediterranean/Middle East. More breadth in worldwide species is required to better understand the potential of Rhus as a commercial source of natural antioxidants [31].

Brine shrimp lethality assay is a prescreening technique for determination of cytotoxic potential of natural products [32]. Stem and leaves extracts of $R$. punjabensis prepared in different solvent systems showed noteworthy activities (Table 3 ) with $\mathrm{LC}_{50}(50 \%$ lethal concentration) ranging from 36.7 to $93.3 \mu \mathrm{g} / \mathrm{mL}$. n-hex leaf extract showed highest cytotoxic effect against brine shrimps $\left(\mathrm{LC}_{50} 36.7 \pm 0.56 \mu \mathrm{g} / \mathrm{mL}\right)$ followed by $\mathrm{CHCl} 3$ extract $\left(\mathrm{LC}_{50} 38.5 \pm 0.65 \mu \mathrm{g} / \mathrm{mL}\right)$. The degree of lethality is normally presumed directly proportional to the potency of extract. The results suggest that use of moderately polar solvent for extraction is a better option for isolation of compounds with cytotoxic capability, rather than a highly polar or non-polar solvent. The results of cytotoxic assay in current study showed lower values of $\mathrm{LC}_{50}$ than previously reported in $R$. lancea $L$ leaves $(600 \mu \mathrm{g} / \mathrm{mL})$. Brine shrimp cytotoxicity assay is widely used as initial procedure for exploration of antimicrobial, antitumor, antifungal, antimalarial, molluscicidal, larvicidal and insecticidal activities [33]. In recent years, the Chinese herbal medicine has been used the allied species of Rhus discussed widely as a new alternative for carious diseases. The results of this assay depict that $R$. punjabensis may have more hidden potential for the discovery of bioactive compounds in addition to the present investigation.

Significant protein kinase inhibition was observed by $\mathrm{MeOH}$ extract of leaves $(50 \mu \mathrm{g} /$ disc). While in case of stem, the highest activity was found by $\mathrm{MeOH}$ extract (Table 3). Overall maximum protein kinase inhibitory potential was found the polar organic solvents. Researchers around the world have shown interest in the identification of kinase inhibitors which can lead to the development of new drugs for chemopreventive measures [34]. Deregulation of protein kinases is a key factor that play vital role in the pathogenesis of disease [35]. Point mutations in tyrosine kinases and phosphatidylinositol 3kinase catalytic (PI3KCA) subunit in colorectal and gastric cancer [36] and epidermal growth factor receptor activating kinase mutation in glioblastoma [37] are few examples of such deregulations. Protein kinase inhibitors block the aerial hyphae formation of Streptomyces sp., thus may be hypothesized to inhibit the cancer cell proliferation [12].

The in vitro cytotoxic values of extracts against THP1human leukemic cell line are presented in Table $3 . \mathrm{CHCl}_{3}$ 
Table 3 Cytotoxic, antileishmanial and protein kinase inhibitory activities of $R$. punjabensis leaf and stem extracts

\begin{tabular}{|c|c|c|c|c|c|c|c|c|}
\hline \multirow[t]{3}{*}{ Samples } & \multicolumn{2}{|c|}{$\begin{array}{l}\text { Brine shrimp cytotoxicity } \\
(\mu \mathrm{g} / \mathrm{ml})\end{array}$} & \multicolumn{2}{|c|}{$\begin{array}{l}\text { Cytotoxicity against leishmanial } \\
\text { promastigotes }(\mu \mathrm{g} / \mathrm{ml})\end{array}$} & \multicolumn{2}{|c|}{$\begin{array}{l}\text { THP-1 cytotoxicity } \\
(\mu \mathrm{g} / \mathrm{ml})\end{array}$} & \multirow{2}{*}{\multicolumn{2}{|c|}{$\begin{array}{l}\text { Protein kinase inhibition } \\
(\mu \mathrm{g} / \text { disc }) \\
{ }^{*} \text { Diameter }(\mathrm{mm}) \text { at } 100 \\
\mu \mathrm{g} / \text { disc }\end{array}$}} \\
\hline & \multirow{2}{*}{$\begin{array}{l}\text { \% Mortality } \\
200\end{array}$} & \multirow[t]{2}{*}{$\mathrm{LC}_{50}$} & \multirow{2}{*}{$\begin{array}{l}\% \text { Mortality } \\
100\end{array}$} & \multirow[t]{2}{*}{$\mathrm{I}_{50}(\mu \mathrm{g} / \mathrm{mL})$} & \multirow{2}{*}{$\begin{array}{l}\% \text { Mortality } \\
10\end{array}$} & \multirow[t]{2}{*}{$\mathrm{I}_{50}$} & & \\
\hline & & & & & & & Clear zone & Bald zone \\
\hline \multicolumn{9}{|l|}{ Leaf } \\
\hline n-hex & $100 \pm 4.10$ & $36.7 \pm 0.56$ & $98.2 \pm 3.12$ & $15.78 \pm 0.77$ & - & - & $7 \pm 0.51$ & - \\
\hline $\mathrm{CHCl3}$ & $98 \pm 3.11$ & $38.5 \pm 0.65$ & $90.7 \pm 3.05$ & $18 \pm 0.18$ & $64.2 \pm 0.71$ & $7.8^{* * *} \pm 0.61$ & $6 \pm 0.62$ & - \\
\hline Acet & $96 \pm 3.00$ & $52.2 \pm 0.66$ & $95.3 \pm 3.18$ & $21.60 \pm 0.25^{* * *}$ & $26.1 \pm 0.10$ & $>10$ & - & $9 \pm 0.7$ \\
\hline Acet + EtOAc & $92 \pm 2.75$ & $58.7 \pm 0.71^{* * *}$ & $75 \pm 1.19$ & $35.43 \pm 0.41$ & $61.9 \pm 0.71$ & $8.1^{* *} \pm 0.71$ & $8 \pm 0.73$ & - \\
\hline EtOAc & $86 \pm 1.31$ & $64.5 \pm 0.78$ & $72 \pm 1.22$ & $64.50 \pm 0.62^{* *}$ & - & - & - & $6 \pm 0.56$ \\
\hline $\mathrm{EtOH}$ & $82 \pm 1.16$ & $62.7 \pm 0.81^{* *}$ & $66.4 \pm 0.75$ & $75.40 \pm 1.17$ & - & - & - & $12.5 \pm 1.71^{* * *}$ \\
\hline $\mathrm{MeOH}$ & $65 \pm 0.75$ & $86.2 \pm 1.18 \mathrm{e}$ & $63.6 \pm 0.66$ & $81.60 \pm 1.12$ & $40.4 \pm 0.61$ & $>10$ & - & $13.5 \pm 1.11^{* * *}$ \\
\hline $\mathrm{MeOH}+\mathrm{CHCl} 3$ & $67 \pm 0.71$ & $88.1 \pm 1.51$ & $69.3 \pm 0.80$ & $77.75 \pm 1.23^{*}$ & $35.7 \pm 0.21$ & $>10$ & - & $11 \pm 0.87^{* *}$ \\
\hline $\mathrm{EtOH}+\mathrm{CHCl} 3$ & $62 \pm 0.72$ & $87.9 \pm 1.30$ & $54.6 \pm 0.57$ & $97.8 \pm 3.11^{*}$ & - & - & - & $11 \pm 0.88^{* *}$ \\
\hline $\mathrm{EtOH}+\mathrm{EtOAc}$ & $68 \pm 0.81$ & $82.3 \pm 1.11^{*}$ & $68.2 \pm 0.77$ & $57.41 \pm 0.75$ & - & - & $6.5 \pm 0.11$ & - \\
\hline $\mathrm{MeOH}+$ EtOAcet & $57 \pm 0.55$ & $93.2 \pm 1.75$ & $72.7 \pm 1.01$ & $54.55 \pm 0.71$ & - & - & $6.6 \pm 0.12$ & - \\
\hline \multicolumn{9}{|l|}{ Stem } \\
\hline n-hex & $100 \pm 4.13$ & $39.6 \pm 0.65$ & $62.6 \pm 0.80$ & $75.74 \pm 1.10^{* *}$ & - & - & $8 \pm 0.75$ & - \\
\hline $\mathrm{CHCl} 3$ & $98 \pm 2.16$ & $43.9 \pm 0.56 b$ & $52.8 \pm 0.56$ & $78.72 \pm 1.19$ & $54.7 \pm 0.71$ & $8.4^{* *} \pm 0.72$ & $9.5 \pm 0.98$ & - \\
\hline Acet & $87 \pm 1.33$ & $55.1 \pm 0.60^{*}$ & $48.1 \pm 0.46$ & $>100$ & $52.3 \pm 0.70$ & $8.9^{*} \pm 0.88$ & $6.5 \pm 0.65$ & - \\
\hline Acet + EtOAc & $76 \pm 1.18$ & $62.7 \pm 0.77^{* * *}$ & $46.6 \pm 0.41$ & $>100$ & - & - & $6.5 \pm 0.66$ & - \\
\hline $\mathrm{EtOAc}$ & $78 \pm 1.19$ & $59.5 \pm 0.56^{* *}$ & $49.2 \pm 0.51$ & $>100$ & - & - & $8 \pm 0.85$ & - \\
\hline $\mathrm{EtOH}$ & $72 \pm 1.15$ & $64.4 \pm 0.68$ & $56.7 \pm 0.80$ & $97.73 \pm 3.15^{* * *}$ & - & - & $7.5 \pm 0.62$ & - \\
\hline $\mathrm{MeOH}$ & $75 \pm 1.17$ & $68.7 \pm 0.71^{* *}$ & $52.2 \pm 0.90$ & $95.58 \pm 1.10$ & - & - & - & $12.5 \pm 1.12^{* * *}$ \\
\hline $\mathrm{MeOH}+\mathrm{CHCl} 3$ & $62 \pm 0.72$ & $68.3 \pm 0.72$ & $28.4 \pm 0.07$ & $>100$ & $16.6 \pm 0.11$ & $>10$ & - & $8 \pm 0.66$ \\
\hline $\mathrm{EtOH}+\mathrm{CHCl} 3$ & $45 \pm 0.09$ & $>200$ & $26.7 \pm 0.05$ & $>100$ & - & - & - & $10 \pm 0.75^{* *}$ \\
\hline $\mathrm{EtOH}+\mathrm{EtOAC}$ & $42 \pm 0.07$ & $>200$ & $18.7 \pm 0.08$ & $>100$ & - & - & - & $9 \pm 0.96$ \\
\hline $\mathrm{MeOH}+\mathrm{EtOAC}$ & $48 \pm 0.07$ & $>200$ & $14.4 \pm 0.07$ & $>100$ & - & - & $7 \pm 0.70$ & - \\
\hline Doxorubicin & $100 \pm 4.10$ & $5.75 \pm 0.07$ & & & & & & \\
\hline Flourouracil & & & & & $99.6 \pm 4.19$ & $5.1 \pm 0.11$ & & \\
\hline Vincristine & & & & & $98.1 \pm 3.17$ & $8.1 \pm 0.92$ & & \\
\hline Surfactin & & & & & & & & $17 \pm 1.02$ \\
\hline Amphotercin-B & & & $100 \pm 4.01$ & $1.36 \pm 0.11$ & & - & - & - \\
\hline 1\% DMSO in PBS/sea water & - & & - & & - & & & \\
\hline DMSO & & & & & & & & - \\
\hline
\end{tabular}

*Zone of inhibition including the diameter of disc $(5 \mathrm{~mm})$. Data was analyzed individually in triplicate $(n=1 \times 3)$. Data is presented as highly significant***, slightly significant**, significant* at $p<0.05$. - : no activity. LSD and HSD applied in all the data

extract of leaves and stem showed good anticancerous effect $\left(\mathrm{LC}_{50} 7.8 \pm 0.61 \mu \mathrm{g} / \mathrm{mL}\right.$ and $8.4 \pm 0.72 \mu \mathrm{g} / \mathrm{mL}$, respectively), which is comparable to standard drugs 5 -florouracil and vincristine $\left(\mathrm{LC}_{50} 5.1 \mu \mathrm{g} / \mathrm{mL}\right.$ and $8.1 \mu \mathrm{g} / \mathrm{mL}$, respectively). The cytotoxic activity against cell lines might be attributed to the presence of molecules which have the ability to modify the signal transduction pathways; flavonoids responsible for inhibitory effects on protein kinases and some transcriptional factors [38], protein tyrosine kinase inhibitor, molecules that cause cell cycle arrest, and apoptosis by a p53-dependent mechanism [39]. The compounds isolated from $R$. succedanea $\mathrm{L}$ have shown significant cytotoxic activity against five cancer cell lines including cervix epithelioid carcinoma (HeLa), hepatoma cell line (Huh7), colorectal cancer cell line (HCT116), colon adenocarcinoma (LoVo), and rat C6 glioma cells [40]. The brine shrimp lethality assay also showed good relationship with cytotoxic activities against THP1 cell line in 
the current exploration. The results are in consistent with the literature where the significant cytotoxic, anticancer activity against carcinogenic $\mathrm{Cdc} 25$ phosphatases was unveiled by $R$. chinensis Mill [41] and $R$. verniciflua stokes against mouse embryonic primary hepatic cells (MPHC), embryonic normal hepatic cell line (BNL CL.2), and SV40mediated transformed cell line (BNL SV A.8) [42, 43]. The similarity in the results of some assays suggest that $R$. punjabesis may also have the similar potential for drug discovery as the other allied species of this genus.

The antibacterial activity of extracts from leaves and stem parts of $R$. Punjabensisare shown in Table 4. The extracts producing a growth inhibitory zone of $\geq 10 \mathrm{~mm}$ in agar disc diffusion assay are considered active and further evaluated for MIC determination through broth micro dilution method. All the extracts were significantly effective against tested bacterial strains. Among all, M. Luteus and S. Typhimurium strains were found most susceptible by the Acet and EtOAc leaf extract, producing zones of inhibition of $18 \pm 1.5$ and $22 \pm$ $1.5 \mathrm{~mm}$ with MIC of 11.11 and $1.11 \mu \mathrm{g} / \mathrm{mL}$, respectively. $\mathrm{MeOH}+\mathrm{CHCl}_{3}$ stem extract depicted maximum growth inhibition zone $(16 \pm 1.7 \mathrm{~mm})$ with MIC 11.1 and $33.33 \mu \mathrm{g} / \mathrm{mL}$ against $M$. luteusand $P$. aeruginosa, respectively. The antimicrobial properties of herbal plants largely depends upon solvent used, organism tested and plant part used. Various species of Rhus genus have been documented to possess the antibacterial activities [4]. The allied species of Rhus; R. glabra is traditionally used by native peoples of North America in the treatment of bacterial diseases such as syphilis, gonorrhea, dysentery, and gangrene. R. coriaria which grows wild in the region from the Canary Islands through the Mediterranean region to Iran and Afghanistan [44]. Now a day, world is

Table 4 Antibacterial activities of leaf and stem extracts of R. punjabensisin terms of zone of inhibition (ZOI) and their MICs

\begin{tabular}{|c|c|c|c|c|c|c|c|c|c|c|}
\hline \multirow[t]{2}{*}{ Extracts } & \multicolumn{10}{|c|}{ Zone of inhibition $(\mathrm{mm})$ at $100 \mu \mathrm{g} / \mathrm{disc}$ and $\mathrm{MIC}(\mu \mathrm{g} / \mathrm{mL})$} \\
\hline & $P$. aeruginosa & $\mathrm{MIC}$ & S. typhimurium & MIC & M. luteus & $\mathrm{MIC}$ & B. bronchiseptica & $\mathrm{MIC}$ & S. aureus & MIC \\
\hline \multicolumn{11}{|l|}{ Leaf } \\
\hline n-hex & - & - & - & - & - & - & $13 \pm 1.24^{* * *}$ & $33.3^{c}$ & $12 \pm 1.17^{*}$ & $33.3^{c}$ \\
\hline $\mathrm{CHCl} 3$ & - & - & - & - & - & - & $08 \pm 0.49$ & - & $11 \pm 1.16$ & 100 \\
\hline Acet & $10 \pm 1.15$ & 100 & $13 \pm 1.29^{*}$ & 33.3 & $18 \pm 1.85^{* * *}$ & $11.11^{\mathrm{ab}}$ & $14 \pm 1.23^{* *}$ & $33.3^{c}$ & $08 \pm 0.66$ & - \\
\hline EtOAc & $10 \pm 1.14$ & 100 & $22 \pm 2.25^{* * *}$ & $1.11^{\mathrm{a}}$ & $14 \pm 1.12$ & $11.11^{\mathrm{ab}}$ & $11 \pm 1.19$ & 100 & $12 \pm 1.26$ & 100 \\
\hline $\mathrm{EtOH}$ & $06 \pm 0.56$ & - & $10 \pm 1.19$ & 100 & $13 \pm 1.56$ & $33.3^{c}$ & $12 \pm 1.11^{*}$ & 100 & $11 \pm 1.18$ & 100 \\
\hline $\mathrm{MeOH}$ & $14 \pm 1.66^{*}$ & $33.3^{\mathrm{ab}}$ & - & - & - & & $06 \pm 0.25$ & - & $18 \pm 19.6$ & $11.11^{\mathrm{ab}}$ \\
\hline $\mathrm{EtOH}+\mathrm{CHCl} 3$ & $10 \pm 1.11$ & 100 & $10 \pm 1.18$ & 100 & $18 \pm 1.65^{* * *}$ & $11.11^{\mathrm{ab}}$ & $16 \pm 1.59^{* *}$ & $33.3^{c}$ & $08 \pm 0.77$ & - \\
\hline $\mathrm{MeOH}+\mathrm{CHCl} 3$ & - & - & $13 \pm 1.55$ & $33.3^{c}$ & $10 \pm 1.13$ & $33.3^{c}$ & $09 \pm 0.98$ & - & $09 \pm 0.85$ & - \\
\hline $\mathrm{EtOH}+\mathrm{EtOAc}$ & $12 \pm 1.55$ & $33.3^{\mathrm{ab}}$ & $18 \pm 2.98^{* * *}$ & $11.3^{\mathrm{ab}}$ & $15 \pm 1.44^{* *}$ & $11.11^{\mathrm{ab}}$ & $10 \pm 1.12$ & 100 & $13 \pm 1.26^{* *}$ & 33.3 \\
\hline $\mathrm{MeOH}+\mathrm{EtOAC}$ & $13 \pm 1.65^{*}$ & $33.3^{a b}$ & $15 \pm 1.12^{* *}$ & $11.11^{\mathrm{cb}}$ & $15 \pm 1.73^{* *}$ & $11.11^{\mathrm{ab}}$ & $10 \pm 1.12$ & 100 & $08 \pm 0.66$ & - \\
\hline Acet + EtOAc & $15 \pm 1.84^{* *}$ & $11.11^{\mathrm{a}}$ & $14 \pm 1.51^{*}$ & $11.11^{\mathrm{cb}}$ & $20 \pm 2.93^{* * *}$ & $1.11^{\mathrm{a}}$ & $11 \pm 1.11$ & 100 & $13 \pm 1.56$ & $33.3^{c}$ \\
\hline \multicolumn{11}{|l|}{ Stem } \\
\hline n-hex & - & - & $13 \pm 1.37$ & 100 & $10 \pm 1.17$ & - & $12 \pm 1.24$ & 100 & $14 \pm 1.97^{* *}$ & $33.3^{c}$ \\
\hline $\mathrm{CHCl} 3$ & $05 \pm 0.78$ & - & $10 \pm 1.14$ & 100 & - & - & $11 \pm 1.14$ & - & $06 \pm 0.57$ & - \\
\hline Acet & $11 \pm 1.27$ & 100 & $15 \pm 1.58^{* *}$ & 33.3 & $11 \pm 1.15$ & 100 & $13 \pm 1.67^{* *}$ & $33.3^{c}$ & $10 \pm 1.16$ & - \\
\hline EtOAc & $11 \pm 1.26$ & 100 & $11 \pm 1.71$ & 100 & $14 \pm 1.29^{* *}$ & $33.3^{c}$ & $13 \pm 1.68$ & - & $10 \pm 1.17$ & - \\
\hline $\mathrm{EtOH}$ & $10 \pm 1.17$ & 100 & $10 \pm 1.17$ & 100 & $10 \pm 1.15$ & - & $13 \pm 1.74$ & - & $15 \pm 1.53^{* *}$ & $33.3^{c}$ \\
\hline $\mathrm{MeOH}$ & - & - & $07 \pm 0.88$ & - & - & - & $10 \pm 1.14$ & - & $12 \pm 1.25$ & - \\
\hline $\mathrm{EtOH}+\mathrm{CHCl} 3$ & - & - & $07 \pm 0.79$ & - & $12 \pm 1.19$ & 100 & $12 \pm 1.12$ & - & $10 \pm 1.17$ & - \\
\hline $\mathrm{MeOH}+\mathrm{CHCl} 3$ & $16 \pm 1.97$ & $33.3^{\mathrm{ab}}$ & $07 \pm 0.89$ & - & $16 \pm 1.67^{* *}$ & $11.1^{\mathrm{ab}}$ & $08 \pm 0.41$ & - & $11 \pm 1.27$ & - \\
\hline $\mathrm{EtOH}+\mathrm{EtOAc}$ & $13 \pm 1.10^{* *}$ & $33.3^{a b}$ & $12 \pm 1.10$ & 100 & $11 \pm 1.27$ & & $15.5 \pm 1.97^{* *}$ & $11.11^{\mathrm{ab}}$ & $11 \pm 1.21$ & - \\
\hline $\mathrm{MeOH}+\mathrm{EtOAc}$ & $08 \pm 0.98$ & & $10 \pm 1.55$ & & $12 \pm 1.37$ & 100 & $09 \pm 0.77$ & - & $08 \pm 0.89$ & - \\
\hline Acet + EtOAc & $11 \pm 1.81$ & 100 & $12 \pm 1.73$ & 100 & $11 \pm 1.21$ & - & $10 \pm 1.18$ & - & $08 \pm 0.88$ & - \\
\hline Cefixime & $26 \pm 2.98$ & 1.1 & $25 \pm 2.93$ & 1.1 & $24 \pm 2.71$ & 1.1 & $24 \pm 2.92$ & 1.1 & $23.5 \pm 2.71$ & 1.1 \\
\hline Roxithromycin & $26.5 \pm 2.95$ & 0.1 & $25 \pm 2.53$ & 0.1 & $26.5 \pm 2.84$ & 0.1 & $26 \pm 2.85$ & 0.1 & $25 \pm 2.32$ & 0.1 \\
\hline
\end{tabular}

Values (mean \pm SD) are average of three samples of each plant extract, analyzed individually in triplicate $(n=1 \times 3)$. Means difference is highly significant*** slightly significant**, and significant* at $p<0.05$. The MIC values within the column are statistically analyzed using LSD test at $p<0.05$. The same alphabates represent non-significant difference $-=$ No activity in antibacterial assay or not active (zone $<10 \mathrm{~mm}$ ) for MIC determination 
facing greatest problem of resistance against the conventional antibiotics from the microbial sources. This has largely increased the surge for the discovery of new antimicrobial from the other sources. In the present study, tremendous antibacterial potential of $R$. punjabensis suggests it a good alternate to the antibiotics. Rhus extracts are most notable for their antimicrobial activities [3]. It also propose an in depth study of this plant with complete focus on its antibacterial potential to isolate the lead compounds.

The highest zone of inhibition (14 mm), in case of antifungal activity was found by $\mathrm{MeOH}$ extract of leaf against A. flavus (MIC $50 \mu \mathrm{g} /$ disc) followed by Acet extract of leaf against $A$. fumigatus, while stem extracts showed comparatively less activities against all fungal strains (Table 5). None of the stem and leaves extract was active against $F$. solani and $A$. niger. In previous studies, moderate activity of $R$. glabra. $L$. branches extract has been reported against some fungal strains [45]. R. coriaria. $L$. extracts did not show prominent activity against Candida albicans and Candida tropicalis [46]. Our results are in agreement with previous studies regarding the use of comparatively polar solvents for better extraction of antimicrobial compounds [47-53].

n-hex leaf extract exhibited significant antileishmanial potential with $\mathrm{LC}_{50} 15.78 \pm 0.77 \mu \mathrm{g} / \mathrm{mL}$, followed by the $\mathrm{CHCl}_{3}$ leaf extract $\left(\mathrm{LC}_{50} 18 \pm 0.18 \mu \mathrm{g} / \mathrm{mL}\right)$ while in case of stem extract highest activity was observed by $\mathrm{n}$-hex $\left(\mathrm{LC}_{50} 75.74 \pm 1.10^{* \mathrm{~g}} \mu \mathrm{g} / \mathrm{mL}\right)$. These results are differing to findings in that polar extract (methanol) of $R$. aucheri Boiss and $R$. retinorrhaeasteud. ex. A were found more active against leishmanial promastigotes $[54,55]$. The development of resistance to the first line drugs and worldwide scattering of leishmaniasis has led to the increased demand of new therapies for the abolition of this disease necessitating further research in this aspect [56].

Table 5 Antifungal activity of leaf and stem extracts of $R$. punjabensistested against filamentous fungi

\begin{tabular}{|c|c|c|c|c|c|}
\hline \multirow[t]{2}{*}{ Samples } & \multicolumn{5}{|c|}{${ }^{*}$ Diameter of growth inhibition zone at $100 \mu \mathrm{g} / \mathrm{disc}$} \\
\hline & A. fumigatus & Mucorspecies & A. niger & F. solani & A. flavus \\
\hline \multicolumn{6}{|l|}{ Leaf } \\
\hline n-hex & - & $11 \pm 0.8$ & - & - & - \\
\hline $\mathrm{CHCl} 3$ & - & - & - & - & - \\
\hline Acet & $13 \pm 1.21^{* * *}$ & - & - & - & - \\
\hline Acet + EtOAc & - & - & - & - & $11.5 \pm 1.55^{*}$ \\
\hline EtOAC & $7.5 \pm 0.74$ & - & - & $7 \pm 0.77$ & - \\
\hline $\mathrm{EtOH}$ & - & $09 \pm 0.74$ & - & - & $09 \pm 0.95$ \\
\hline $\mathrm{MeOH}$ & - & - & - & - & $14 \pm 1.7^{* * *}$ \\
\hline $\mathrm{MeOH}+\mathrm{CHCl} 3$ & $12 \pm 1.17^{* *}$ & - & - & - & - \\
\hline $\mathrm{EtOH}+\mathrm{CHCl} 3$ & - & - & - & - & $11.2 \pm 1.6^{*}$ \\
\hline $\mathrm{EtOH}+\mathrm{EtOAC}$ & - & - & - & - & $10 \pm 1.3$ \\
\hline $\mathrm{MeOH}+$ EtOAcet & - & - & - & - & $11 \pm 1.9^{*}$ \\
\hline \multicolumn{6}{|l|}{ Stem } \\
\hline n-hex & - & - & $07 \pm 0.57$ & - & - \\
\hline $\mathrm{CHCl} 3$ & - & $7.5 \pm 0.74$ & - & - & - \\
\hline Acet & - & $7.5 \pm 0.84$ & - & - & - \\
\hline Acet + EtOAc & - & $10 \pm 1.16$ & - & - & $09 \pm 0.86$ \\
\hline EtOAc & - & $10.5 \pm 1.17$ & - & - & $11 \pm 1.15^{*}$ \\
\hline $\mathrm{EtOH}$ & - & - & - & - & - \\
\hline $\mathrm{MeOH}$ & - & $7.5 \pm 0.97$ & - & - & - \\
\hline $\mathrm{MeOH}+\mathrm{CHCl} 3$ & - & $7.5 \pm 0.84$ & - & - & - \\
\hline $\mathrm{EtOH}+\mathrm{CHCl} 3$ & - & - & - & - & $9.5 \pm 0.75$ \\
\hline $\mathrm{EtOH}+\mathrm{EtOAc}$ & - & $7.5 \pm 0.75$ & - & - & - \\
\hline $\mathrm{MeOH}+$ EtOAcet & - & $08 \pm 0.85$ & - & - & - \\
\hline Terbinafine & $25.5 \pm 2.25$ & $24 \pm 2.52$ & $23 \pm 2.81$ & $25 \pm 2.84$ & $25 \pm 2.94$ \\
\hline DMSO & - & - & - & - & - \\
\hline
\end{tabular}

*Zone of inhibition including the diameter of disc $(5 \mathrm{~mm})$. In each disc, the sample size was $100 \mu \mathrm{g}$ per disc $(5 \mu \mathrm{l})$ in disc diffusion assay. -: no activity. Means difference is highly significant ${ }^{* * *}$ slightly significant ${ }^{* *}$, and significant* at $p<0.05$. Values are presented as mean \pm standard error from triplicate investigation 
The research efforts on Rhus extracts indicate a promising potential for the plant family to provide renewable bioproducts with the following desirable bioactivities; antifungal, antiinflammatory, antimicrobial, antimalarial, antioxidant, cytotoxic, hypoglycaemic, and anticancer. As well, the bioactive components can be extracted from the plant material using environmentally benign solvents [3].

\section{Conclusions}

The phytochemical and invitrobiological potential of different solvent extracts of $R$. punjabensis leaves and stem is investigated. The findings of current study support the conception of utilization of multiple solvent systems for complete phytochemical and biological profiling of plants. The results indicate that different organic solvent extracts possesses diverse range of biological activities. Polar solvent extracts may be the potential source of phytochemicals provoking highly significant antioxidant capability as well as protein kinases inhibitor. Similarly moderately polar extract of this plant is remarkably effective against leishmania, brine shrimps and THP1 human leukemia cell line which signifies its cytotoxic potential. Consequently this plant can be used as a potent source of antioxidants, anticancerous and antimicrobial agents. Moreover all the reported activities require bioactivity guided isolation of corresponding extract to isolate the active compounds responsible for the reported biological activities.

\section{Abbreviations \\ DMSO: Dimethyl sulfoxide; DPPH: 2, 2-diphenyl-1-picrylhydrazyl; FRSA: Free radical scavenging activity; $\mathrm{IC}_{50}: 50 \%$ inhibitory concentration; $\mathrm{LC}_{50}$ : Lethal concentration causing 50\% mortality; MIC: Minimum inhibitory concentration; TAC: Total antioxidant capacity; TFC: Total flavonoid contents; TPC: Total phenolic contents; TRP: Total reducing power; ZOI: Zone of inhibition}

\section{Acknowledgements}

The authors are thankful to Dr. Mir Ajab Khan, Department of Plant Sciences, Faculty of Biological Sciences, Quaid-i-Azam University Islamabad, Pakistan for identifying the plant samples.

\section{Funding}

Authors are thankful to University Research Fund Quaid-i-Azam University Islamabad Pakistan for partial funding for this research work.

\section{Availability of data and materials}

The datasets supporting the conclusions of this article are included within the article.

\section{Authors' contributions}

SA executed all experimental work and compiled the data. MA helped in manuscript write up and execution of experiments. BM, MZ and ZKS made substantial contribution in biological evaluation of samples and revision of manuscript. GM and MN contributed in study design, supervised the execution of experiments and revised the manuscript. All authors read and approved the final manuscript.

\section{Competing interests}

The authors declare that they have no competing interest.

\section{Consent for publication}

All authors have read and approved the final manuscript. All authors are also agreed to submit the manuscript in BMC Complementary and Alternative medicine.

\section{Ethics approval and consent to participate}

The manuscript does not contain any data regarding human or animal objects so no need of approval from ethical committee and consent from participants.

\section{Publisher's Note}

Springer Nature remains neutral with regard to jurisdictional claims in published maps and institutional affiliations.

\section{Author details}

${ }^{1}$ Department of Biotechnology, Faculty of Biological Sciences, Quaid-i-Azam University Islamabad, Islamabad 45320, Pakistan. ${ }^{2}$ Department of Pharmacy, Faculty of Biological Sciences, Quaid-i-Azam University Islamabad, Islamabad 45320, Pakistan. ${ }^{3}$ Department of Biochemistry, Faculty of Biological Sciences, Quaid-i-Azam University Islamabad, Islamabad 45320, Pakistan.

Received: 23 September 2016 Accepted: 4 March 2017

Published online: 09 March 2017

\section{References}

1. Kossah $R$, et al. Optimization of extraction of polyphenols from Syrian Sumac. Res J Phytochemistry. 2010;4(3):146-53.

2. Kossah $\mathrm{R}$, et al. Comparative study on the chemical composition of Syrian sumac (Rhus coriaria L.) and Chinese sumac (Rhus typhina L.) fruits. Pak J Nutr. 2009;8(10):1570-4.

3. Rayne S, Mazza G. Biological activities of extracts from sumac (Rhus spp.): a review. Plant Foods Hum Nutr. 2007;62(4):165-75.

4. Shabbir A. Rhus coriaria linn, a plant of medicinal, nutritional and industrial importance: a review. J Anim Plant Sci. 2012;22(2):505-12.

5. Lev E, Amar Z. "Fossils" of practical medical knowledge from medieval Cairo. J Ethnopharmacol. 2008;119(1):24-40.

6. Sezik E, et al. Traditional medicine in Turkey X. Folk medicine in central Anatolia. J Ethnopharmacol. 2001;75(2):95-115.

7. Clarke G, et al. High correlation of 2, 2-diphenyl-1-picrylhydrazyl (DPPH) radical scavenging, ferric reducing activity potential and total phenolics content indicates redundancy in use of all three assays to screen for antioxidant activity of extracts of plants from the Malaysian rainforest. Antioxidants. 2013;2(1):1-10

8. Haq IU, et al. Antioxidant and cytotoxic activities and phytochemical analysis of Euphorbia wallichii root extract and its fractions. Iran J Pharm Res. 2012;11(1):241.

9. Jafri $L$, et al. In vitro assessment of antioxidant potential and determination of polyphenolic compounds of Hedera nepalensis Arabian Journal of Chemistry. 2014. http://dx.doi.org/10.1016/j.arabjc.2014.05.002.

10. Haq IU, et al. Antioxidant and cytotoxic activities and phytochemical analysis of euphorbia wallichii root extract and its fractions. Iran J Pharm Res. 2012;11(1):241-9.

11. Hogg JS, Lohmann DH, Russell KE. The kinetics of reaction of 2, 2-diphenyl1-picrylhydrazyl with phenols. Can J Chem. 1961;39:1588-94.

12. Yao $\mathrm{G}$, et al. Citrinin derivatives from the soil filamentous fungus penicillium sp. H9318. J Braz Chem Soc. 2011;22(6):125-1129.

13. Bibi G, et al. Antitumor, cytotoxic and antioxidant potential of Aster thomsonii extracts. Afr J Pharm Pharmacol. 2011;b5(2):252-8.

14. Ihsan-Ul-Haq A, et al. Antibacterial activity and brine shrimp toxicity of Artemisia dubia extract. Pak J Bot. 2012;44(4):1487-90.

15. Kaushik P, Goyal P. In vitro evaluation of Datura innoxia (thorn-apple) for potential antibacterial activity. Indian J Microbiol. 2008;48(3):353-7.

16. Khan I, et al. Comparative study of green fruit extract of melia azedarach Linn. With its ripe fruit extract for antileishmanial, larvicidal, antioxidant and cytotoxic activity. Am J Phytomedicine Clin Ther. 2014;2(2):442-54.

17. Luximon-Ramma A, et al. Antioxidant activities of phenolic, proanthocyanidin, and flavonoid components in extracts of Cassia fistula. J Agric Food Chem. 2002;50(18):5042-7.

18. Kim J-S, et al. Rhus verniciflua Stokes flavonoid extracts have anti-oxidant, antimicrobial and a-glucosidase inhibitory effect. Food Chem. 2010;120(2):539-43. 
19. Wu T, et al. Evaluation of antioxidant activities and chemical characterisation of staghorn sumac fruit (Rhus hirta L.). Food Chem. 2013;138(2):1333-40.

20. Zaitoun S, Al-Ghazawi A, Al-Qudah A. Bee pollination and fuit set of Sumac (Rhus coriaria, Anacardiaceae) as a native herbal plant grown under semiarid Mediterranean conditions in Jordan. Adv Hortic Sci. 2007;21(3):183-7.

21. Cho N, et al. Cognitive-enhancing effects of Rhus verniciflua bark extract and its active flavonoids with neuroprotective and anti-inflammatory activities. Food Chem Toxicol. 2013;58:355-61.

22. Chua LS, 3. A review on plant-based rutin extraction methods and its pharmacological activities. J Ethano Pharmacol. 2013;150:805-17.

23. Mehrdad M, et al. Validated high-throughput HPLC method for the analysis of flavonol aglycones myricetin, quercetin, and kaempferol in rhus coriaria L. Using a monolithic column. J AOAC Int. 2009;92(4):1035-43.

24. Kosar M, et al. Antioxidant activity and phenolic composition of sumac (Rhus coriaria L.) extracts. Food Chem. 2007;103(3):952-9.

25. Jung $\mathrm{CH}$, et al. Rhus verniciflua stokes extract: radical scavenging activities and protective effects on $\mathrm{H} 2 \mathrm{O} 2$-induced cytotoxicity in macrophage RAW 264.7 cell lines. Biol Pharm Bull. 2006;29(8):1603-7.

26. Gülçin I, et al. Radical scavenging and antioxidant activity of tannic acid. Arab J Chem. 2010;3(1):43-53.

27. Viuda-Martos M, et al. Antioxidant activity of essential oils of five spice plants widely used in a Mediterranean diet. Flavour Fragr J. 2010;25(1):13-9.

28. Özcan MM, Erel Ö, Herken EE. Antioxidant activity, phenolic content, and peroxide value of essential oil and extracts of some medicinal and aromatic plants used as condiments and herbal teas in Turkey. J Med Food. 2009; 12(1):198-202.

29. Bursal E, Köksal E. Evaluation of reducing power and radical scavenging activities of water and ethanol extracts from sumac (Rhus coriaria L.). Food Res Int. 2011;44(7):2217-21.

30. Seeram NP, Nair MG. Inhibition of lipid peroxidation and structure-activityrelated studies of the dietary constituents anthocyanins, anthocyanidins, and catechins. J Agric Food Chem. 2002;50(19):5308-12.

31. Pokorný J. Natural antioxidants for food use. Trends Food Sci Technol. 1991;2:223-7.

32. Krishnaraju AV, et al. Assessment of bioactivity of Indian medicinal plants using brine shrimp (Artemia salina) lethality assay. Int J Appl Sci Eng. 2005; 3(2):125-34

33. Silva EC, et al. Biological activity of neosergeolide and isobrucein B (and two semi-synthetic derivatives) isolated from the Amazonian medicinal plant Picrolemma sprucei (Simaroubaceae). Mem Inst Oswaldo Cruz. 2009;104(1):48-56.

34. Bain J, et al. The selectivity of protein kinase inhibitors: a further update. Biochem J. 2007:408:297-315.

35. Blume-Jensen P, Hunter T. Oncogenic kinase signalling. Nature. 2001; 411(6835):355-65.

36. Samuels $Y$, et al. High frequency of mutations of the PIK3CA gene in human cancers. Science. 2004;304(5670):554-4.

37. Pearson MA, Fabbro D. Targeting protein kinases in cancer therapy: a success?. Expert Rev Anticancer Ther. 2004;4(6):1113-24.

38. Miranda C, et al. Antiproliferative and cytotoxic effects of prenylated flavonoids from hops (Humulus lupulus) in human cancer cell lines. Food Chem Toxicol. 1999;37(4):271-85.

39. Le Marchand L. Cancer preventive effects of flavonoids - a review. Biomed Pharmacother. 2002;56(6):296-301.

40. Wu P-L, et al. Antioxidative and Cytotoxic Compounds Extracted from the Sap of Rhus s uccedanea. J Nat Prod. 2002;65(11):1719-21.

41. Djakpo O, Yao W. Rhus chinensis and Galla Chinensis-folklore to modern evidence: review. Phytother Res. 2010;24(12):1739-47.

42. Son Y-O, et al. Selective antiproliferative and apoptotic effects of flavonoids purified from Rhus verniciflua Stokes on normal versus transformed hepatic cell lines. Toxicol Lett. 2005;155(1):115-25.

43. Gupta S, Afaq F, Mukhtar H. Selective growth-inhibitory, cell-cycle deregulatory and apoptotic response of apigenin in normal versus human prostate carcinoma cells. Biochem Biophys Res Commun. 2001;287(4):914-20.

44. Gabr SA. Beneficial effects of sumac extract on biochemical changes in senile rats. J Radiat Res Appl Sci. 2011;4(1A):33-43.

45. McCutcheon A, et al. Antifungal screening of medicinal plants of British Columbian native peoples. J Ethnopharmacol. 1994;44(3):157-69.

46. Digrak M, Alma MH, Ilçim A. Antibacterial and antifungal activities of Turkish medicinal plants. Pharm Biol. 2001;39(5):346-50.
47. Salie $F$, Eagles $P$, Leng $H$. Preliminary antimicrobial screening of four South African Asteraceae species. J Ethnopharmacol. 1996;52(1):27-33.

48. Parekh J, Karathia N, Chanda S. Screening of some traditionally used medicinal plants for potential antibacterial activity. Indian J Pharm Sci. 2006;68(6):832.

49. Masoko P, Eloff J. Bioautography indicates the multiplicity of antifungal compounds from twenty-four southern African Combretum species (Combretaceae). AJB. 2006;5(18):1625-47.

50. Bisignano G, et al. Drugs used in Africa as dyes: II. Antimicrobial activities. Phytother Res (United Kingdom). 1996;10(5):346-50.

51. Lourens A, et al. In vitro biological activity and essential oil composition of four indigenous South African Helichrysum species. J Ethnopharmacol. 2004:95(2):253-8.

52. Rojas JJ, et al. Screening for antimicrobial activity of ten medicinal plants used in Colombian folkloric medicine: a possible alternative in the treatment of non-nosocomial infections. BMC Complement Altern Med. 2006;6(1):2.

53. Addai ZR, Abdullah A, Mutalib SA. Effect of extraction solvents on the phenolic content and antioxidant properties of two papaya cultivars. JMPR. 2013;7(46):3354-9.

54. Michael A, Thompson C, Abramovitz M. Artemia salina as a test organism for bioassay. Science. 1956;123:464.

55. Camacho $M$, et al. Screening of plant extracts for antiprotozoal and cytotoxic activities. J Ethnopharmacol. 2003;89(2):185-91.

56. Al-Harmni KIF, AL-Khan HI, Fattohy Zl. Effect of Aqueous Extract of Melia azedarach on the some Biochemical Parameters in the Liver Extract of Infected Mice by Lieshmania donovani. Diyala J Med. 2011;1(2):44-55

\section{Submit your next manuscript to BioMed Central and we will help you at every step:}

- We accept pre-submission inquiries

- Our selector tool helps you to find the most relevant journal

- We provide round the clock customer support

- Convenient online submission

- Thorough peer review

- Inclusion in PubMed and all major indexing services

- Maximum visibility for your research

Submit your manuscript at www.biomedcentral.com/submit
Biomed Central 